\title{
THE HISTORICAL DEVELOPMENT OF LOCAL GOVERNMENT ADMINISTRATION AND ITS CONTEMPORARY REALITIES IN NIGERIA
}

\author{
Etebom John Monday (1), Junior Hendri Wijaya (2)
}

(1) Department of Local Government and Development Studies, Obafemi Awolowo University, Nigeria

(2) College of Village Community Development "APMD", Indonesia

Email Korespondensi: jmetebom@oauife.edu.ng;

\begin{abstract}
Abstrak: Pemerintah daerah adalah pemerintah di akar rumput yang paling dekat dengan masyarakat. Ini adalah tingkat administrasi pemerintahan yang mengoordinasikan kegiatan warga di tingkat komunitas lokal. Pemerintah daerah sebagai konsep pemerintahan sudah ada jauh sebelum kedatangan penjajah. Ada bentuk administrasi pemerintah lokal di Nigeria sebelum pemerintahan kolonial. Selama kolonialisme, sistem pemerintahan tidak langsung Inggris dibangun di atas administrasi lokal yang ada di Nigeria. Namun, tidak demikian halnya bagi pemerintah daerah terkait struktur dan organisasi di tanah air saat ini. Studi ini melakukan rontgen berbagai fase dan era pembangunan pemerintah daerah di Nigeria. Ini lebih lanjut menganalisis realitas administrasi lokal saat ini di negara ini. Penelitian ini menggunakan pendekatan kualitatif. Data kualitatif diperoleh dari tanggapan wawancara dari pemangku kepentingan terkait (seperti tokoh adat dan staf administrasi senior pemerintah daerah). Juga, data dikumpulkan dari literatur relevan yang ada. Data yang terkumpul dianalisis dengan menggunakan metode analisis konteks. Studi tersebut mengungkapkan bahwa administrasi pemerintah daerah di Nigeria telah melewati fase-fase yang menyiksa. Ini mengidentifikasi kurangnya otonomi pemerintah daerah antara lain sebagai tantangan utama yang mengganggu perkembangannya di negara ini. Kajian ini diakhiri dengan rekomendasi untuk memposisikan kembali pemerintah daerah untuk pemberian layanan yang efektif sebagai pemerintah tingkat ketiga Nigeria.
\end{abstract}

Kata kunci; Daerah; Administrasi; Realitas; Tingkat; Kolonialisme;

\begin{abstract}
Local government is the government at the grassroots closest to the people. It is the tier of government administration that coordinates the activities of citizens at the local community levels. Local government as a concept of government existed long before the arrival of the colonialists. There were forms of local government administrations in Nigeria before colonial rule. During colonialism, the British's indirect rule system was built upon existing local administrations in Nigeria. However, the story is not the same for local government administration regarding structure and organization in the country today. The study $\mathrm{x}$-rayed the various phases and eras of local government development in Nigeria. It further analyzed the present realities of local administration in the country. The study employed a qualitative approach. The qualitative data were generated from interview responses from relevant stakeholders (such as Traditional leaders and senior local government administrative staff). Also, data were gathered from existing relevant literature. Data collected were analyzed using the context analysis method. The study revealed that local government administration in Nigeria has passed through torturous phases. It identified the lack of local government autonomy amongst others as the main challenge bedevilling its development in the country. The study concluded with recommendations to reposition local government for effective service delivery as Nigeria's third tier of government.
\end{abstract}

Keywords: Local; Administration; Realities; Tier; Colonialism;

Article Information: Submitted: 2022-01-06; Revised 2022-01-20; Accepted: 2022-02-10

\section{(cc) BY-SA}

This work is licensed under

Creative Commons Attribution-ShareAlike 4.0 International License. 


\section{INTRODUCTION}

The concept of local government as a tier of government has generated exciting debates among scholars in the academic world, practitioners and politicians alike. It has attracted the attention of various scholars across the globe, thereby resulting in various conceptualizations by different scholars. The need to conceptualize what local government is arising because it is the unit of analysis in this study, and different meanings/names are being used in different countries in referring to local government as a tier of government.

Local government as a concept that refers to people at the grassroots is as old as the human race itself. Its concept can be traced to when humans lived in communal and feudal settlements. The history of local government administration in Nigeria predicts its existence as an entity and can be traced to the pre-colonial era.

Agagu (2011:72) posited that:

Local government administration has undergone a very long and tortuous journey in Nigeriafrom the diversities of the pre-colonial era, through the lugard's experiment and the travails of the military adventurists and the military guided democracy. The local government in Nigeria has developed its peculiarities and forms. Any meaningful attempt to thoroughly study local government in Nigeria will amount to studying the government and politics in Nigeria.

Local government administration has passed through torturous phases of development in the country, from pre-colonial settlements, colonial rule, independence local council administration, military rule, the 1976 local government reform to the fourth republic. Since independence, several governments have made attempts to ensure that the local government is the closest to the people, engineers the drive for development through democratic participation and efficient service delivery (see Etebom, 2019, Adeyeye, 2016, Agagu, 2011, Gboyaga, 2003). However, there is little or nothing to show for these efforts at the grassroots level in the country. There is no uniform structure and administration local government system in the country despite its constitutional provision (Etebom, 2019, Agagu, 2011).

The development of local government administration in Nigeria took a new turn since the return of the country to democracy on May 29, 1999, after long years of military rule. The hope of Nigerians was high that expectedly, democratic government would lead to good governance viz-a-viz enthronement of due process, constitutionality, respect for the rule of law, transparency, accountability and, free and fair elections. However, the reverse is the case, especially at the local government levels, which has made genuine democracy elude the grassroots in Nigeria. The consequences are a lack of meaningful socio-economic development at the local level, which should typically provide a solid foundation for the nation's infrastructural development and security (Aluko, 2010).

The study analyzed the historical development of local government administration from the precolonial rule, where the different communities and kingdoms, later known as Nigeria, lived in peace and harmony with varying governance systems. It furthers empirically discussed local government administration under military rule analyzed the 1976 local government reform where has been described as the bedrock of local government development in the country and the contemporary realities bedevilling local government administration in the country. The concluding section of the study revealed the contemporary realities of local government administration viz-a-viz. Other challenges such as state interference, constitutional ambiguity, lack of electoral uniformity all hinge on the lack of local government autonomy as the clog on the wheel of local government development in the country.

\section{Evolution of Local Government Administration in Nigeria \\ Pre-Colonial and Colonial Local Administration}

Before the advent of colonial rule in Nigeria, local administrations have developed, whether the Hausa-Fulani Emirate in the North, the Oyo Empire in the West and the Igbo Kingdom in the East. There were traditional institutions in operation across the country upon which the colonists built the native administration. There were established pockets of traditional administration set-ups fashioned along the lines of a King, Emir, Oba or Head of a family lording over his subjects using traditional councils in large communities in existence in pre-colonial Nigeria. (Mukoro,2003; Ola\&Tonwe,2009; Agagu,2011; Onajide,1997; Egonmwan,1990). 
There was a centralized system of government in the Hausa-Fulani Emirate, a decentralized system of government in the Oyo Empire with no transparent cut system of government in the Igbo Kingdom. The Igbo kingdom operated a family/compound-controlled system with representatives of family/compound forming the leadership structure in each community (Etebom, 2019).

The amalgamation of Northern and Southern protectorate in 1914 and the subsequent introduction of indirect rule or the native administration across the country succeeded in the Fulani/Hausa Emirate and the Oyo Empire, where traditional institutions were better organized respected. The British adopted the indirect rule to preserve and use the authority of existing local institutions in the country. Sir Donald Cameron, a British officer who worked with Lugard, collaborated the overhead view, he argued that:

We desire to make (the chief) a good African. He said this objective could not be achieved if we destroyed all the institutions, traditions, and habits of the people and superimposed upon them what we consider better administrative methods and principles. (Mukoro, 2003). The native authority system had developed rather slowly over a quarter of the century. However, from the mid-1940s, the pace of development accelerated for several factors from different sources and directions, including the creation of regional councils and the review of the native administration system by Richard constitution of 1946, among other factors (Onajide, 1997).

This became a turning point in the development of native authority and local government in Nigeria. As the journey for self-government gathered more momentum in the 1950s, the Macpherson constitution of 1957 introduced parliamentary democracy into Nigeria and local council's law. The status was the native authority law of 1954, and the instruments were the chief and council, the chiefin-council, the federated native authority, country council and the municipal councils.

The Eastern region was first to initiate a radical change in the operation and administration of local government in 1950. The reason for this was the region's dissatisfaction with the native authority, not only because of the nature and custom of the people but also because of corruption (Mukoro, 2003; Agagu, 2008). In the Western region, the local government law was comprehensively reviewed, and all previous amendments were consolidated in new legislation in 1957; while during this period, the Northern region exercised much refrain in its approach to changes in its native authority given the fact that indirect rule system emanated from its harmony with culture and consent of the people in the region (ibid).

The various kingdoms/regions which Lord Lugard later amalgamated to form the Nigerian state had existing traditional systems through which they governed themselves. They lived in peace and harmony, respecting the traditional institutions of the land.

\section{Post - Colonial Era Local Government}

Colonial-era Local Government administration was associated with Indirect Rule or Native Administrative System introduced by Lord Lugard. The system was a massive success in Hausa-Fulani Northern Nigeria because of its existing centralized structure of the traditional system of government. It also succeeded inYoruba Western Nigeria based on its decentralized traditional structure. The story was different in Igbo Eastern Nigeria because the indirect rule did not suit the existing method of government in the region.

While the closing years of colonial rule witnessed the efforts at installing a liberal democratic system of government, "political decay" soon emerged in place of political development (Egonmwan, 1990). This period from 1960 to 1976 is quite significant in the nation's history, particularly the development of local government. It marks the development and creation of the modern local government system in Nigeria. Since the colonial era, local government administration in the country has shown much divergence across the various parts and regions of the country. The development of local government during the post-independence era was not different. Its development was along regional lines and different development paces across the country - the history of local government administration in the post-independence era in the history of the military in power.

The reforms of the early 1950s in the Eastern and Western parts of the country started on a promising note; But with the military coming into power in 1966, the take-over of local government

\section{$(\mathrm{cc})$ BY-SA}

This work is licensed under

Creative Commons Attribution-ShareAlike 4.0 International License. 
functions by the regional/state governments and the subsequent introduction of varying local government system across the country placed the local government in a precarious position in the country. The Eastern region began the pioneering effort to model local government in Nigeria with its Local Government ordinance of 1950. In terms of structure, it was patterned along with the Western Region's Local Government Law of 1952. The Northern Region also passed the Native Authority Law of 1954. Following the creation of 12 states in 1967, structural rearrangements in the state-local government relationships became inevitable. (Egonmwan,1990; Mukoro,2003; Ola\&Tonwe,2009; Agagu, 2011; Gboyega,1988).

In Northern Nigeria, reforms marked a watering down of the Emir's position and power vis-a-vis the state bureaucracy. Divisional administration and the native authority system were abolished. A twotiered pyramidal structure remained, for instance, in Kano, consisting of a Local Authority and subordinate District authorities. A new wave of local government through popular participation rather than hereditary began to sweep across the Northern states.

In Eastern states, different systems were adopted after the civil war. Essentially the philosophy of local government in war-torn areas was a system of centralization that decentralized powers and functions to the headquarters from the centre or state headquarters'; the system was described as development administration, particularly in the South-East states as Bendel state that was created in 1963. This was clearly stated in the South-East state Development Edict No.7 of 1972 and Bendel State Edict No. 26 of 1974. In the East central state, the home state of the Ibo people, "local administration", was replaced with "local government". According to Wraith (1972:187) cited in Agagu (2011:80), an attempt has been made at the village level to harness ancient indigenous patterns of organization and systems of authority under the generic term "communities" for modern development. The state adopted a divisional administration system following the abolition of the country, councils, and local administration.

The sole administrator system was adopted in Western states but later abandoned for the Local Advisory Council. This was because the sole Administrators became mere advisors to the nominated local council. They attended meetings of the management committee as the watch-dogs of government. The advisory council or committees consisted of ten unpaid members, while the district officers served as chairman. The new arrangement brought about the Agbekoya Riots in West in 1968 and 1969 when they protested tax payment without representation. By 1971, a circular was issued by the ministry of local government equity local government staff with civil servants based on pay and status. These were means to encourage qualified personnel to join the local government council (ibid). In 1973, an internal management system was introduced, a "council-manager system". In the council-manager system, the Chief Executive is the secretary to the council. The manager was not appointed by the council but instead by an independent Local Service Board, an apparatus of the central government (the state governments).

The most remarkable thing about the various reform's measures adopted by the state government was the shift in power, relative financial resources and staffing from the local authorities to the state ministries. According to Egonwman (1990), what was usually not recognized by members of the various reform committee at that time, was that the fundamental changes in central-local relationships were not due to constitutional reasons but due to the underlying economic changes following the creation of states, 12 in 1967, increased to 19 in 1976. He added that, without the transfer of power, some of the newly created state ministries would have had relatively fewer responsibilities than the subordinate level of government. With the increase in the number of states came a drop in the revenue from the government to each state. States then tried to compensate for such losses by acquiring functions, even those purely local nature, because they were lucrative in revenue yielding. The net effect of all this was continued impoverishment of local government and increasing overhead on state government bureaucracies.

In conclusion, the period 1960 to 1976 brought out new experiments in terms of philosophies, structure, innovation, and changes. Agagu (2008) argued that; despite the various reforms across the country, local government still maintained the divergence in its operation till 1976. The implication to him is that without conscious efforts to give direction and a sense of mission to our institutions in the country, the national ideal may be absent. Local governments became cash strapped thereby, being

\section{$(\mathrm{Cc}) \overline{\mathrm{BY}-\mathrm{SA}}$}

This work is licensed under

Creative Commons Attribution-ShareAlike 4.0 International License. 
unable to carry out their statutory duties, hence, the need for a reform of the various local government systems in the country. The federal military government reacted, and the outcome was the setting up of the Public Service Review Commission, whose terms of reference included the review of the local government system in the country. The commission made some recommendations to improve the performance capability of local governments in the country. The recommendations did not see the light of the day before another military government took over power in July 1975. However, in November 1975, working parties comprising local government practitioners and consultants were appointed to advise on the appropriate local government system in the country.

Based on their recommendations partly derived from the Public Service Review Commissions Report, the federal and state governments agreed on the issue of guidelines for local government reform. The policy output was the 1976 Federal Republic of Nigeria Guidelines for Local Government Reform and the promulgation of Local Government Edicts by all the state governments.

\section{The 1976 Local Government Reform}

The 1976 Local Government Reform marked a turning point in the evolution of local government development in Nigeria. The reform has been described as a landmark in the history of local government in the country. It is the bedrock of local government development in the country. Many authors have acknowledged this. According to Ola (1979), "for the first time the Federal government has shown a direct interest spearheaded the reform throughout the country and it was the first time the local government will be recognized as a tier-of-government in Nigeria". For the first time, the reform provided, among other things, a uniform local government system in all the states of the federation. Adamolekun and Roland (1979) argued that what distinguished the reform from other previous ones is the distinct level of government with defined boundaries, clearly started functions and provisions for adequate human and financial resources. General ShahuYar'Adua, the then Chief of Staff, Supreme Headquarters who was the spokesman for the Federal Military Government, justified the reform when he asserted that:

The local government had over the year suffered from a continuous whittling down of powers. The state governments had continued to encroach upon what had been recognized in other countries as the executive preserve of local government. Lack of adequate funds and appropriate institutions has continued to make local government ineffective and inefficient. Moreover, the staffing arrangements to ensure a virile local government system had been inadequate. Excessive politicking had made even modest progress impossible. Consequently, there has been a divorce between the people and government institutions at the most basic level (Federal Government, 1976).

According to Agagu (2011); The 1976 Local Government reform demonstrated a commitment to a new political value nationwide. He further added that it was an essential element of the political transition program of the Murtala/Obasanjo regime and part of the process of building a solid foundation for the return of the democratic government. The federal and state government jointly carried out the reform though the federal government initiated it. It was derived primarily from the Udoji Commission Report set up by the previous military government of General Yakubu Gowon and a nationwide consultation on how to reposition the public service in Nigeria, including the local government (Adeyeye, 2016, Aghavere, 1995)

The guidelines for the 1976 Local Government Reforms highlighted some of the main objectives for establishing a local government system: They include;

1. To make appropriate services development activities responsive to local wishes and initiatives by developing or delegating them to local representatives' bodies. To facilitate the exercise of democratic self-government close to the local levels of our society and to encourage initiative and leadership potential.

2. To mobilize human and material resources through the involvement of the public in their local development and;

3. To provide a two-way channel of communication between local communities and government.

The overall objective of the reform was to revamp the local government system and serve as a broad guideline for local government administration throughout the country. Aghayere (1995) summarized the fundamental areas of the 1976 reform as follows;

\section{(c) BY-SA}

This work is licensed under

Creative Commons Attribution-ShareAlike 4.0 International License. 
1. The functions of local government;

2. The structure of local government;

3. The financial resources of local government;

4. The place of traditional rulers in local government;

5. The relationship with state government;

6. Law enforcement.

The reform provided for two sets of local government functions in Nigeria, with a third one not in statutes but assigned by the appropriate legislative body in intergovernmental content (Adeyeye, 2016). The functions are the exclusive, concurrent and permissive functions. These functions were provided for under section 5 of the reform, and it also found expression in schedule 4 of both the 1979 and 1999 Constitution of the Federal Republic of Nigeria. Some of the main achievements of the reform are:

1. The introduction of a multi-purpose single-tier local government structure in the country. According to the guidelines, each local government area should compose a population of between 150,000 and 800,000 .

2. The issue of finance; called for the federal government financing of local government and local government financing from own sources through internally generated revenue (IGR). The current sharing formula given by the Nigeria senate is the federal government $56 \%$, states $24 \%$ and local government $20 \%$, respectively.

3. The reform clearly stated the relationship between the state and local government, which was a superior-subordinate relationship. Each state was directed to establish a ministry of local government to perform effectively. Although this could not be said to have substantially altered the relationship, it only modified it as the debate for local autonomy in the country in still ongoing.

4. The reform led to the exclusion of traditional rulers from direct participation in local government administration throughout the country. It only assigned consultative advisory roles to traditional institutions. The reform called for a council which are authorized to deal with the chieftaincy, traditional or country matters in each local government area.

5. The reform allows democratic participation at the local levels through the institution of popularly elected representative local government councils throughout the federation. The recruitment of chairpersons and councilors were to be made through direct elections.

It is important to note that the reform had some pitfalls, among which are;

1. The reform deprived the local government of any power of maintaining law and order. It only provided for a police committee that should operate in advisory capacity. The committee was given the responsibility of maintaining a constant review of questions relating to the enforcement of bye-law and other government legislation.

2. The uniformity imposed by the reform on local government in the country contradicts the localists justification of local government based on diversity of local conditions.

Adeyeye (2016) argued that the 1976 Local Government experiment ended on a sour note as most of its policy recommendations, especially the institution of a democratic elected Local Government system, could not be realized. However, one of the enduring features of the reform was its incorporation into the 1979 constitution, which provided the bedrock of subsequent constitutions; viz: 1989, 1999 and 2011 as amended constitutions of the Federal Republic of Nigeria.

\section{Local Government under the Second Republic (1979-1983)}

The military regime took appropriate steps to operationalize the constituent elements of the 1976 Local Government Reform. Elections were held at the local government level throughout the country on a non-party basis in December 1976. Between December 1976 and October 1, 1976, when the military relinquished power to civilians, the military administrations made a commendable effort to resolve problems encountered in the process of implementation of the reform, especially in the sphere of finance and personnel. With the emergence of the Second Republic, the local government system in the country was dissolved by the state government, and elections were not held into the councils until the second coming of the military in December 1983. Instead of elections into local government

\section{(cc) BY-SA}

This work is licensed under

Creative Commons Attribution-ShareAlike 4.0 International License. 
councils in the country, the politicians appointed a management committee to charge local council affairs throughout. Thus, the constitutional guarantee of a system of local government councils could not be realized under the civilian regime.

\section{Local Government under The Buhari/Idiagbon Era (1983-1985)}

The regime of General Buhari dissolved the management committee put in place by the ousted civilian government and took some steps to resuscitate the third tier of government in the country. The regime, stunned by the deplorable state of affairs at the local level in the country, first strove to compress the number of local governments that had been overblown by the politicians back to its original 1979 status. In this respect, sole administrators or senior civil servants were appointed for local government and a 20-member committee headed by Alhaji Ibrahim Dasuki was constituted to look into the problems of local government in May 1984.

However, the committee did not see anything wrong with the 1976 Reform besides operational problems. The report, among other things, attributed the lack of equitable distribution of amenities to different parts of local government areas and stressed the negative roles of state government under the ousted civilian government. Unfortunately, the coup of General Ibrahim Babangida in August 1985 scuttled the implementation of the Dansuki Report.

\section{Local Government under General Babangida Regime (1985-1993)}

The General Ibrahim Babaginda transitional program gave the Local Government Administration all the paraphernalia of a presidential system of government. At the inception of the regime, to arrest the dwindling autonomy of local government, the Federal Government ordered the scrapping of the Ministries of Local Government throughout the country, an institution which the state government has used over the years to police the third tier of government (Ola, 2009). Elections were conducted in all the local government councils throughout the country on a non-party basis on December 12, 1987. The regime abolished the State-Local Government Joint Account and channelled statutory allocations from the Federation Account accrue to local councils directly.

A committee was set up under the chairmanship of Professor Adedotun Philip in 1988. It is called the 1988 Civil Service Reforms. One of its aims was to radically reform the administrative structure and finance of local government in the country (Aghayere, 2010). The reforms as they applied to local government have the objective of professionalizing the Local government services as this is expected to increase performance and service delivery. The committee set up to study the application of the reforms to the local government submitted its report in four weeks.

Section 5(1) of the guidelines for the implication provided that "the chairman of each local government shall be the Chief Executive and Accounting officers of the Local Government...". As an Accounting officer, he is forbidden to sign cheques and vouchers. The same document (Section 1) also provides supervisory councillors who shall be closely and intimately involved in the management of their respective departments. It also provides for popularly elected councillors to make the legislative arm of the local government, while supervisors shall be appointed by the chairman to make up the executive arm of the council. Another local government election was held throughout the country now on party basic in December 1990. It is important to note that the people directly elected the position of the chairpersons, deputies, and councillors during this period.

It is important to note that the 1988 reform contributed significantly to the structure of local government in Nigeria. The guidelines for implementing the local government (Basic constitutional provision) Amendment Decree 1991 are as follows:

1. The local government council (elected members) shall constitute the legislative arm of the local government to be responsible for law-making. One of the councillors shall be chosen as a leader;

2. The chairman shall be the chief executive of local government. He shall be a member of the council;

3. Supervisors are appointed by the chairman either from within or outside the local government system. Each supervisor shall be in charge of a portfolio;

\section{(cc) BY-SA}

This work is licensed under

Creative Commons Attribution-ShareAlike 4.0 International License. 
4. The executive arm of the local government will be made up of the chairman, vice-chairman and the supervisors, and;

5. A secretary to the local government council shall be appointed and serve as the chief administrative adviser to the Executive Arm of the local government.

The guideline specifies, among other things; Separation of power between the executive and legislative

1. arms;

2. The appointment of supervisors

3. The election of a leader.

It has provided for a presidential system of government at the local level. The only structure missing in the local government "Presidentialism" under the regime was the judicial arm present at both the state and federal levels to date.

Another development of the regime was the 1989 constitution which dealt more elaborately with the Local Government than the 1979 Constitution. Section 7 of the constitution is similar in most respects in its provision to the 1979 constitution. There were, however, three additional provisions. Section 7(2) increased the existing number of local government areas from 307 to 449. Section 7(3) also empowers the state to create up to seven development areas regarding standard historical and traditional tiers, geographical contiguity, and administrative experience.

Last but not least, section 7(9) requires the Auditor - General of a state to audit the account of the local governments annually and report the report to be presented before the State House of Assembly. Agagu (2011) agreed that the Babangida regime had the highest number of legislations and circulars on local government since Nigerian's independence. The most notable was the 1988 Local Government Reforms, which introduced Presidentialism at the local level. The overall objectives of these reforms, according to President Babangida, were to make local government a "third tier of government in practice". It is also worthy of note that the Babangida administration has done more for local government than any other government to date. With the changing vision of the General Babangida administration and the accompanying behavioural and structural contradictions, the administration set up a ten-man committee on October 10, 1991, headed by Professor Robert Ola. Some of the committee's terms of reference include the need to undertake a comprehensive review of certain documents in light of the ongoing reforms in the local government system and civil service in the country. The committee sat between October 1991 and January 1992 and developed a very detailed document. However, with the problems that engulfed the country following the annulment of the June 12, 1993, Presidential elections and the eventual take-over of General Sani Abacha, the committee's report could not make the necessary impact. One pertinent observation here is that the various regime reforms laid the foundation for the existing structure of local government in the country.

\section{Local Government the Fourth Republic}

As part of the transition program of General Abubakar Abdulsalams military government to the country democratic rule, local government elections were conducted across the country in December 1998 for a three-year term. At the expiration of the tenure of the local government in 2002, it was expected that the election would be conducted immediately, more so as the country was in a democratic dispensation; unfortunately, this was not to be so (Ola, 2009; Agagu, 2011). Generally, the 1999 constitution of Nigeria paid very little attention to the local government (ibid).

Essentially, Section 7 and the fourth schedule deal with provisions for local government. Section 7 and the fourth schedule of the 1999 constitution are virtually the same things as Section 7 and the fourth schedule of the 1979 constitution. The general observation that the 1999 constitution gives local government little attention derives from the fact that the 1989 constitution made detailed provisions for local government covering elections, powers and tenures of political functionaries, and local government service. According to Agagu (2011), all these show that there was adequate consideration of local government in planning, drafting, and ratifying the 1989 constitution. These, however, were missing in the conception, drafting and adoption of the 1999 Constitution.

Ola (2005) refers to this period as "Uncertainty of the future of local government" Section 7 of the 1999 constitution of the Federal Republic of Nigeria guaranteed" the system of the local government

\section{$(\mathrm{Cc}) \overline{\mathrm{BY}-\mathrm{SA}}$}

This work is licensed under

Creative Commons Attribution-ShareAlike 4.0 International License. 
by democratically elected local government councils; and accordingly, the government of every state shall subject to Section 8 of this constitution, ensure their existence under a law which provides for the establishment, structure, composition, finance and functions of such councils". Despite the constitution's provisions on local government, there was confusion rending the air when democracy was to be ushered in by 1999, as observed by Agagu (2011). People were not sure of the tenure of the local government political officeholders. There is no fixed tenure for elected local government officials. They have been at the mercy of the state Governors since the start of the fourth republic. Each time there is a change of administration as the state, the new government dissolves the elected councils and sets up a caretaker local government committee to be in charge.

\section{The Contemporary Realities of Local Government Administration in Nigeria}

The realities of local government as a third tier of government in the fourth republic are in contradictions with the constitutional provisions of local government and the 1976 local government reform which amongst other things laid the foundation for a uniform structure of local government and democratic local government councils in the country. The ambiguity of the 1999 Constitution viz-a-viz the role of the State Houses of Assembly and State Governors has not helped the development of local government in the Fourth Republic.

The statutory roles of local government have been taken over by the state government. The 1976 reform identified and classified local government functions into three categories. These functions are enshrined under schedule 4 of the 1979 and 1999 constitutions. The first category is, the general functions, the second are the concurrent functions and third, the exclusive functions (Adeyeye, 2016; Ola \& Tonwe, 2009; Aghayere, 2010).

1. The general functions:

Under the general duties local government, local governments are to:

a. Discharge the duties and obligations imposed by law;

b. Assist in maintaining order and good government within the local government area;

c. Prevent the commission of an offence, and

d. Report any act which is likely to result in a serious breach of peace to the nearest police officer court officer or justice of the peace.

2. The exclusive functions:

These are functions which are exclusively reserved for the local government. Local Governments, therefore, have powers to make bye-laws for all the following matters:

i) Establishment, control and regulation of markets and motor parks;

ii) Sanitation, sanitary inspection, sewage and refuse;

iii) Control of vermin;

iv) Slaughter house and slaughter slabs;

v) Registration of births, births, death and marriages;

vi) Cemeteries and burial grounds;

vii) Public convenience;

viii) Provision of community and recreational centres;

ix) Parks, gardens and open spaces;

x) Licensing of bicycle, trucks;

xi) Licensing, supervision and regulation of baking houses, eating houses;

xii) Control of hoarding, advertisement, use of loud speakers in or near public places;

xiii) Naming of roads and streets and numbering of plots and buildings;

xiv)Collection of vehicle parking charges;

xv) Collection of properties and other rates, radio and television licenses and other designated revenues, and

xvi)Licensing of hack carriages and regulation of traffic and parking.

3. The concurrent functions:

These are functions in which the state government and other organizations or agencies may perform part or whole of these functions where the Local Governments do not have capacity to perform the functions. These functions include the followings:

\section{(cc) BY-SA}

This work is licensed under

Creative Commons Attribution-ShareAlike 4.0 International License. 
(i) Hospital (except specialist and teaching hospitals), health centres, maternity centres, health clinics, ambulance services, leprosy clinic;

(ii) Preventive health centres;

(iii) Provision and maintenance of primary institutions other than polytechnics and university education;

(iv) Information and public enlightenment;

(v) Provision of Public Libraries and reading rooms

(vi) Development of agriculture and natural resources, including forestry;

(vii) Water supply;

(viii) Provision of roads than trunk roads, their lightening and drainage;

(ix) Support of arts and culture;

(x) Control of pollution;

(xi) Control of beggars, prostitutes and reparation of the destitute;

(xii) Provision of home for the destitute, infirm and orphans;

(xiii) Provision of public utilities including roads and water supply;

(xiv) Regulation and control of buildings;

(xv) Public housing programs;

(xvi) Town and country planning;

(xvii) Operation of commercial undertakings;

(xviii) Piped sewage system, and

(xix) Control of soil erosion.

Another reality of local government in fourth republic is the lack of democratic local councils as provided for in the 1999 constitution. Elections have not held in many states and where they are held, there are issues varying from imposition of candidate to rigging of the elections (Adeyeye, 2016; Etebom, 2019). Etebom, 2019 argued that,

The structure of local government in the country varies from one state to another depending largely on the disposition of the state government. Some states have caretaker committee systems like Akwa - Ibom, Nasarawa, Kaduna, some democratic local councils like Lagos, Sokoto, Benue, while sole administrator system is in practice in Kogi state. The situation is not different in Southwestern Nigeria. Lagos and Ogun states have been consistent in the conduct of local government elections. They have held council elections four times respectively since 1999. Ekiti and Oyo have been fairly regular in the conduct of local government elections, having held it three times. Caretaker committees have been holding sway at the grassroots level in Ondo and Osun states. They have held council elections in both states two times since the country returned to democratic rule. The council manager system of local government administration used in the old Western Region was in practice in Osun state. This as well are against the provisions of the Constitution, Section 7(1), which states that "...the system of local government by democratically elected local government councils is under this Constitution guaranteed..."

The major reality of contemporary local government administration in Nigeria is the LACK OF LOCAL GOVERNMENT AUTONOMY on which other challenges bedeviling its development hinges. Although, the 1999 constitution made provisions for the independence operation of local government administration in the country, events have over the years and especially in the fourth republic proven otherwise. As discussed earlier in the study, the structure and operations of local government administration is largely determined by the disposition of each state government in the country. This has largely impeded the development of local government viz-a-viz effective service delivery, citizen's participation, true representation, uniform structure and good governance at the grassroots across the country.

To collaborate the above assertion, a head of administration and general service in the local government that was interviewed as a respondent on the subject of local government autonomy explained that "local government autonomy can only be said to be in place in a system where the people elect their leaders themselves and the funding of local government is not done by the state as against

\section{(cc) BY-SA}

This work is licensed under

Creative Commons Attribution-ShareAlike 4.0 International License. 
the provision of the Constitution". In other words, it comes directly from the source, that is, the federal government to the local governments. The chairperson of NULGE in one of the local governments in Osun state opined that local government being under the state government with an undefined autonomy affects local government development. He posited until there is clear and defined local government autonomy; elections could not be credible and consistent. He further added that the state has always have control and influence over local government; that was why local government elections were not conducted in the state for about 10 years.

A head of administration in the state asserted that democratic system of local government is not in existence in Nigeria again. He further added that none of the elected councillors and chairmen can boast of winning council elections on their own without the influence and help of the state governors. So, they have no effrontery to say their mandate is democratically given. And with this across board in local governments, there cannot be good governance at the local government level in the country. When asked further why there are no meaningful developments as the grassroots in the country, A director in Osun State Ministry of Local Government Affairs posited that:

It is because there is no autonomy. What comes to local government in terms of resources is so little and no local government official either elected or appointed can make any major impact with such. Not ruling out corruption and other sharp practices, if local officials have the resources, they will perform and deliver on good governance. Local governments have qualified personnel in all fields but lack the resources to perform optimally. The statetakes all the decisions and those there are answerable to the governor and not the people. The main challenge is for the country to practice true federalism where each tier will be responsible and accountable to the people.

Also, a paramount traditional ruler in Osun state argued that:

there are no two ways to it, one thing leads to another. If there is autonomy at the local government level, the elected official will be accountable to the electorate and where there is accountability there will be good governance and development. We are where we are as a nation because our leaders are not accountable to us. Until we get to the stage where our votes and voice matters, there cannot be good governance especially at the grassroots.

\section{CONCLUSION AND RECOMMENDATIONS}

The study revealed that the lack of defined local government autonomy occasioned by the ambiguity of the 1999 constitution on local government is the fundamental reality affecting the development of local government administration in the country.

The study recommended the urgent need for an amendment of the constitution to grant local government defined autonomy to enable it operates as a true tier of government.

\section{REFERENCE}

Adeyeye, M.O. (2016). Governing The Localities: Lessons (UN) Learnt, 284 Series Inaugural Lecture, An Inaugural Lecture Delivered at Oduduwa Hall, Obafemi Awolowo, University Ile Ife, Nigeria, on Tuesday, $22^{\text {nd }}$ March, 2016.

Agagu, A.A. (2011). Theory and Practice of Local Government, Policy and Consultants Ltd, Akure

Agagu, A. (2004). Continuity and Change in Local Government Administration and the Politics of Underdevelopment. In: Agagu, A. \& Ola, R. (eds). Development Agenda of Nigeria State. Ibadan: Fiag Publishers.

Agbakoba, O. and Ogbonna, H. (2004). Local Government Administration and Development in Nigeria, Lagos: Hurilaws. Ajayi, K. (2000). Justification and Theories of Local Government. In: Ajayi .K. (ed). Theory and Practice of Local Government Ado-Ekiti. Department of Political Science, University of Ado-Ekiti.

Federal Republic of Nigeria. (1999).The 1999 Constitution. Lagos, Federal Government Press

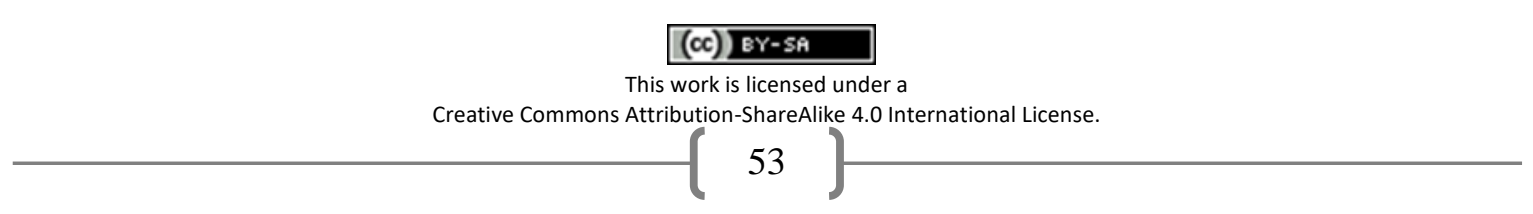


Aluko, J.O. (2010). Local Government Elections and The Challenges of Democratic Governance in Nigeria, www.nigeriaworld.com>articles>aug accessed on 4/07/2017

Aghayere, V.O (2010). Local Government in Nigeria since 1950 in Ola, R.F and Imhanlahimi, J.E (ed). Nigeria Political System: Trends Perspectives, University of Benin Press, Benin City

Federal Republic of Nigeria. (1976). The 1976 Guidelines on Local Government Reforms in Nigeria, Federal Ministry of Information, Lagos.

Gboyega, A. (1983). Local Government Reforms in Nigeria in Philips Mawhood (ed) Local Government in Third World, Chichester John Wiley and Sons.

Egonmwan, J.A (1990). Principles and Practices of Local Government in Nigeria, S.M.O. Aka \& Brother Press, Benin City.

Ola, R. F. (1984). Local Administration in Nigeria. London: Kegan Paul International.

OIa, R. O. \&Tonwe, D. A. (2003). Local Government Administration and Local Government in Nigeria, Trust Publishing, Lagos.

Ola, R.O.F. and Tonwe, D.A. (2009). Local Administration and Local Government in

Nigeria, Lagos: Amfitop Book.

Onajide, M. O (1997). Evolution of Local Government and National Economy in Nigeria,

Comfort Press and Publishing Company Ltd, Ikeja Lagos. 